\title{
ASPEK SOSIAL GEMPA BUMI 27 MEI 2006 \\ DI KABUPATEN BANTUL
}

\author{
Oleh: \\ Soemantri Wardoyo \\ Jurusan Pendidikan Geografi, FISE UNY
}

\begin{abstract}
Abstrak
Gempa dapat mengakibatkan kerusakan bentang alam, makhluk hidup, dan bangunan fisik. Manusia sebagai korbannya menjadi bagian penting dalam peristiwa gempa. Apa yang dialami oleh manusia akibat gempa, aspeknya meliputi aspek fisik dan aspek nonfisik. Aspek fisik meliputi luka ringan, luka berat, cacat permanen, dan meninggal dunia. Aspek nonfisik meliputi gangguan kejiwaan sehubungan dengan kehilangan harta benda, suami/isteri, anak, saudara, tetangga, maupun mitra kerja. Aspek non fisik yaitu aspek sosial merupakan aspek yang memerlukan perhatian lebih terutama pasca gempa. Pendampingan $d \epsilon$ ngan tenaga yang memadai diperlukan untuk pemulihannya.
\end{abstract}

Kata kunci: aspek sosial, gempa bumi

\section{Pendahuluan}

Pokok pesan yang diungkap dalam tulisan ini lebih banyak berkaitan dengan aspek sosial dan ekonomi, sedangkan aspek kegempaannya sendiri sudah banyak ditulis oleh ahli kegempaan. Dalam tulisan ini akan dipaparkan empat hal yaitu: kejadian, penanganan, pendanaan/pembiayaan, dan pasca gempa. Gempa bumi sendiri sebagai peristiwa alam dapat terjadi kapan saja. IImu dan teknologi hasil rekayasa manusia sampai saat ini telah dapat menemukan alat deteksi dini. Namun demikian hasil perkiraannya masih belum mencapai tingkat ketepatan yang tinggi. Berbeda dengan peristiwa alam lain yang sama-sama mengakibatkan terjadi bencana. Tanda-tanda akan adanya gunung berapi meletıs sudah dapat diketahui lebih dini yaitu dengan naiknya suhu udara 
di badan dan kaki gunung berapi, satwa yang turun dari lereng menuju ke kaki, bahkan gempa yang terjadi (gempa vulkanik) merupakan tanda-tanda awal kemungkinan akan terjadi letusan. Gempa bumi tektonik belum dapat diperoleh tanda-tanda awalnya.

\section{Kejadian Gempa}

Gempa sebagai penyebab terjadinya bencana dapat dibahas mengenai sebab, besaran getaran, dan akibat yang ditimbulkan. Sebab terjadinya gempa oleh adanya kekuatan yang ada dalam lapisan bumi, yaitu dapur magma. Kekuatan yang ada pada lapisan bumi disebabkan adanya pergeseran lapisan bumi (lempeng benua), terjadinya patahan pa da lapisan bumi, selanjutnya terjadi runtuhan masa lapisan bumi sehingga menimbulkan getaran yang dahsyat di permukaan bumi. Gempa bumi jenis ini disebut gempa bumi tektonik. Gempa bumi yang terjadi 27 Mei 2006 di Kabupaten Bantul D.I. Yogyakarta, menurut para ahli gempa tergolong gempa tektonik.

Getaran yang terjadi dapat diukur dengan tingkat ketepatan yang tinggi dengan alat ukur Richter, menghasilkan catatan berupa grafik yang menggambarkan kekuatan getaran gempa. Dengan skala yang telah ditetapkan dapat disebut besaran getaran berdasar Skala Richter. Besarnya angka skala dipengaruhi oleh kekuatan getaran dan jarak alat ukur dari pusat gempa. Makin besar angka yang dicatat, makin besar kekuatan getaran. Oleh karena itu gempa tektonik sebagaimana terjadi di wilayah Kabupaten Bantul hampir setahun yang lalu tercatat 5,6 skala Richter. Angka tersebut sudah tergolong gempa dengan kekuatan sedang sampai tinggi.

Getaran selain dapat diukur kekuatannya juga dapat diukur lama waktu terjadi getaran tersebut. Hitungan waktu tercatat dengan alat pengukur waktu gempa. Berdasar waktu yang tercatat, gempa di wilayah Kabupaten Bantul lama waktunya kurang dari satu menit. Sekalipun terhitung pendek waktunya, oleh karena berkekuatan 5,6 skala Richter, maka korban kerusakan tergolong besar. Korban dan kerusakan tergolong besar, di samping karena kekuatan getaran besar, juga karena terjadi di wilayah padat penduduk.

Frekuensi kejadian terutama jenis gempa tektonik oleh para at.li telah dapat diramalkan periode kejadiannya. Kejadian seperti di Kabupaten 
Bantul diperkirakan akan terjadi lagi dalam kurun waktu 70 sampai 100 tahun lagi. Sementara itu untuk jenis gempa tektonik akan sering terjadi gempa susulan yang skalanya lebih kecil. Hal ini terjadi sangat mungkin oleh karena rongga yang terdapat dalam lapisan bumi sebagai akibat adanya pergeseran patahan berproses menuju keseimbangan dan kestakilan. Tenggang waktu dari waktu kejadian sampai keadaan stabil diperkirakan dua sampai tiga bulan. Dalam waktu dua sampai tiga bulan tersebut gempa susulan dapat terjadi sampai ratusan kali.

Akibat kejadian gempa dapat dikelompokkan: kerusakan terhadap bentang alam, makhluk hidup, dan bangunan fisik. Kerusakan bentang alam berupa retakan, patahan, air sumur mengeruh sampai kering, lahan mengalami rekahan dan menganga sampai puluhan meter. Kerusakan bentang alam ini juga akan berakibat kerusakan tumbuh-tumbuhan, binatang, hewan ternak, bangunan, dan manusia.

Hewan tidak luput dari gangguan oleh kejadian gempa ini. Hewan piaraan banyak yang mati, lepas dari kandang sampai hilang. Sedang yang masih hidup menjadi stres sehingga tidak berproduksi untuk beberapa lama. Pepohonan dan tanaman dapat condong hingga membahayakan bagi bangunan rumah tinggal maupun fasilitas umum. Sedang yang tumbang dapat melintang di jalan atau menimpa bangunan, hewan ternak, pepohonan lain, kabel telepon dan listrik, juga manusia.

Korban manusia menjadi bagian yang penting dalam peristiwa gempa. Begitu banyak hal yang perlu mendapat perhatian. Apa yang dialami oleh manusia pada saat kejadian dan pasca kejadian, aspeknya meliputi fisik, nonfisik, material, dan sosial ekonomi. Aspek fisik meliputi luka ringan, berat sampai kecacatan permanen dan meninggal dunia. Oleh karena wilayah Kabupaten Bantul tergolong daerah padat penduduk, korban manusia meninggal sampai ribuan orang, demikian pula yang luka ringan, berat, dan kecacatan. Aspek nonfisik meliputi gangguan kejiwaan sehubungan dengan kehilangan harta benda, suami atau isteri, anak, saudara, tetangga, maupun mitra kerja.

Kerusakan bangunan meliputi bangunan rumah tinggal, bangunan pelayanan publik, tempat pendidikan, rumah ibadah, jalan, dan jembatan. Semua kerusakan tersebut akan menjangkau kehidupan sosial dan ekonomi penduduk. Banyak keluarga kehilangan tempat berteduh karena ambruk atau rusak parah, sehingga berbahaya apabila dihuni. Mereka 
terpaksa menempati tenda yang didirikan untuk tempat tinggai sementara. Keadaan darurat ini tidak hanya mengganggu kesehatan fisik tetapi juga kejiwaan, terlebih-lebih bagi para lanjut usia dan balita. Secara ek.onomis tidak sedikit yang terpaksa kehilangan atau berhenti kegiatan ekonominys karena kerusakan bangunan usaha dan Iahan. Bahkan tidak sedikit yang terpaksa kehilangan pekerjaan karena pemutusan hubungan kerja.

\section{Penanganan Gempa}

Penanganan terhadap korban gempa, kerusakan harca benda dan yang lain, perlu penetapan prioritas. Hal ini perlu diambil sehubungan dengan sifat korban dan kerusakan yang terjadi. Sementara itu juga terkait dengan ketersediaan dana dan tenaga, korban manusia tentu mendapatkan prioritas pertama. Mereka yang meningga' dunia, luka berat sampai ringan perlu segera mendapat pertolongan. Kesiapsiagaan semua pihak yang belum genap menyebabkan penanganan bencana tidak terstruktur dan tidak sistematis. Fase kedaruratan atau emergency response yang difokuskan untuk menyelamatkan penyintas (survivor) dari kematian atau lebih menderita akibat bencana harus diakui tidak maksimal. Bantuan darurat seperti shelter/tempat berlindung, makanan, air bersih, sanitasi dan pelayanan kesehatan amat terlambat dan tidak merata (Suparlan, 2006).

Berikutnya adalah perbaikan jaringan listrik dan jalan, hal ini perlu karena terkait dengan keselamatan dan keamanan wilayah. Sedang sarana jalan terkait dengan penyaluran logistik bagi para korban dan keluarganya. Bantuan berupa bahan makanan, obat-obatan, pakaian, dan tenda untuk pembuatan tempat tinggal sementara. Bangunan rumah tinggal banyak yang roboh, mengalami rusak berat sampai ringan. Bangunan yang roboh maupun rusak berat tidak layak huni dan berbahaya, maka kepada keluarga seperti ini perlu mendapat tempat berteduh sementara berupa tenda. Obatobatan dan relawan medis sangat diperlukan untuk menolong korban yang mengalami luka berat maupun ringan. Suasana menjadi sangat mencekam karena banyaknya korban. Lalu lalang orang dari tempat lain yang akan memperoleh informasi keadaan orang tua, saudara, kenalan, maupun mitra kerja menambah suasana semakin sibuk. Sementara itu tidak sedikit yang hanya datang sekedar menonton suasana. Pada saat yang mencekam tersebut suasana duka mendalam dialami oleh keluarga korban. 
Ternyata perhatian dari pemerintah maupun anggota keluarga dan masyarakat umum sangat besar. Lembaga swadaya masyarakat bahkan badan-badan internasional ikut ambil bagian memberi bantuan berupa bahan makan, obat-obatan, pakaian, dan bahan bangunan. Mereka dengan suka rela memberikan bantuan melalui Posko yang mereka dirikan untuk menyalurkan bantuan. Posko berkoordinasi dengan pemerintah daerah bahu membahu meringankan beban penderitaan para korban.

Apabila diamati dengan seksama dapat diketahui bahwa kampung, dusun, atau keluarga yang di antara anggota dan sanak famili berada di tempat lain memberikan perhatian dan bantuan yang sangat berarti. Berbeda clengan kampung, dusun, desa, atau keluarga yang tidak mempunyai warga berada di tempat lain, mereka hanya mengandalkan bantuan dari pemerintah. Waktu penerimaan pun tidak secepat yang lain, bahkan dapat terjadi keterlambatan.

Prioritas selanjutnya adalah sarana pelayanan publik dan tempattempat ibadah. Dalam suasana yang memprihatinkan tersebut ternyata solidaritas antar warga dan keluarga lain di tempat lain menjadi semakin kentara. Melalui berita radio, televisi, dan sarana lain mempercepat proses penyampaian keadaan daerah gempa.

Menurut Insist (2006), upaya penanganan bencana gempa melalui 3 tahap, yakni tahip tanggap darurat (emergency response), tahap peralihan (transitional), dan tahap pemulihan dan penataan kembali.

1. Tahap Tanggap Darurat (emergency response)

Tahap tanggap-darurat adalah masa pelayanan bantuan kemanusiaan langsung kepada para korban sejak hari pertama terjadinya bencana. Lama tahap ini terutama bergantung pada besarnya dampak kerusakan yang diakibatkan oleh bencana tersebut. Terhadap bencana gempa bumi 27 Mei 2006 di Jogyakarta dan sebagian Jawa Tengah, diperkirakan masa tanggap-darurat berlangsung sekitar sebulan penuh, yakni sampai akhir Juni 2006.

Tujuan dan sasaran utama tahap ini adalah membantu memenuhi kebutuhan pokok hidup sehari-hari para korban agar tidak semakin menderita dian mampu bertahan hidup sampai keadaan kembali pulih kembali. Oleh karena itu, kegiatan utama pada tahap ini adalah penyaluran bantuan kemanusiaan dalam bentuk penyediaan 
pangan dan sandang, tempat penampungan sementara (darurat), pelayanan kesehatan, dan sebagainya.

2. Tahap Peralihan (transitional)

Tahap ini merupakan masa-singkat beranjak keluar (phasing out) dari tahap tanggap-darurat ke tahap berikutnya, yakni tahap pemulihan dan penataan kembali. Dengan kata lain, tahap ini pada dasarnya adalah masa persiapan sosial untuk memulai kembali kehidupan wajar (normal) mereka seperti sediakala atau ke taraf yang lebih baik lagi dalam jangka-panjang di masa mendatang.

Untuk itu, tujuan dan sasaran utama tahap ini adalah terbentuknya Badan Pemulihan dan Penataan Desa (BPPD), pada beberapa desa terpilih sebagai 'tim inti' yang akan menggerakkan warga masyarakat lainnya untuk melakukan proses-proses pemulihan dan penataan kembali semua prasarana kehidupan dan kelembagaan sosial-ekonomi desa mereka. Sesuai tujuan dan sasarannya, maka strategi dasar yang ditempuh pada tahap ini adalah menumbuhkan kembali kesadaran harga-diri dan martabat mereka sebagai manusia (setelah trauma bencana) serta semangat kesetiakawanan clan kegotong-royongan tradisional mereka sebagai suatu kaum (community).

3. Tahap pemulihan dan penataan kembali (reconstruction and rehabilitation)

Tahap ini merupakan tahap inti yang sesungguhnya dari seluruh proses penanganan bencana dan pelayanan korban yang diakibatkannya. Berdasarkan pengalaman selama ini, tahap inilah justru yang paling sering dilupakan, atau dianggap sebagai tanggungjawab utama pemerintah saja. Akibatnya, banyak prosesproses pemulihan dan penataan kembali di banyak daerah bencaria selama ini, khususnya di Indonesia, berlangsung dalam suatu kerangka pendekatan yang serba-terpusat, mengabaikan asas partisipasi masyarakat dan otonomi kelembagaan sosial lokal. Oleh karena itu tahap ini semestinya sebagai prioritas utama di kawasan bencana di Jogyakarta dan Jawa Tengah.

Tujuan dan sasaran utama dari tahap ini adalah menciptakan suatu 'model' pemulihan dan penataan kembali berbasis masyarakat (community-based reconstruction and rehabilitation). Secara garis- 
besar, kegiatan-kegiatan utama pada tahap ini, antara lain, mencakup: (1) Pembangunan kembali perumahan dan lingkungan pemukiman penduduk berbasis kebutuhan dan kemampuan mereka sendiri (community-based housing), dengan penekanan pada aspek sistem sanitasi lingkungan organik daur-ulang; (2) Penataan kembali prasarana utama desa, khususnya yang berkaitan dengan sistem produksi pertanian; (3) Pembangunan basis-basis perekonomian desa dengan pendekatan penghidupan berkelanjutan, terutama pada kedaulatan dan keamanan pangan (food security and sovereignty) dan ketersediaan energi yang dapat diperbaharui (renewable energy); serta perintisan model sistem kesehatan desa yang terjangkau dan efektif.

\section{Pendanaan}

Pada dasarnya bencana alam tidak dapat diperkirakan kapan te jadinya. Demikian pula bentuk dan tempatnya tidak dapat diduga sebelumnya. Akan tetapi adanya bencana alam sebagai peristiwa alam yang sewaktu-waktu dan di sembarang tempat dapat terjadi, maka dalam hal penyediaan dana menjadi. sangat tentatif, sekalipun demikian dalam Anggaran Pendapatan Negara maupun daerah disediakan mata anggaran bantuan sosial. Dana yang disediakan oleh pemerintah dalam hal percairannya tidak semudah yang dibayangkan, karena anggaran pemerintah harus dapat dipertanggungjawabkan dengan baik. Bantuan logistik berupa bahan pangan dan pakaian dapat lebih cepat disampaikan sekalipun harus mengikuti prosedur birokrasi yang agak panjang. Semua itu dalam rangka penyelamatan dana bantuan supaya tepat sasaran. Sedangkan batuan dari lembaga swasta dan perorangan lebih fleksibel, sangat tergantung hubungan antara pemberi bantuan dengan korban. Lebih-leblh bantuan dari perorangan sekalipun jumlahnya tidak terlalu besar tetapi segera dapat diterimakan dan tepat sasaran.

Bantuan dari luar negeri baik atas nama pemerintah, lembaga swastia, maupun perorangan demikian besar. Bantuan yang berasal dari pemerintah harus mengikuti prosedur antar pemerintah, sedang yang berasal dari lembaga swasta sangat tergantung sifat lembaga tersebut, ada yang berkoordinasi dengan pemerintah pusat atau daerah. Bantuan dari perorangan dapat diperoleh tergantung hubungan personal antara keluarga korban dengan orang asing tersebut. Bantuan dapat berupa paket 
pembangunan rumah tinggal, bangunan pelayanan publik, makanan, obatobatan, dan pakaian.

Prosedur penyampaian bantuan tidak semudah dibayangkan oleh korban. Korban demikian memerlukan batuan, baik bahan pangan, obatobatan, pakaian, maupun yang lainnya. Pada keadaan demikian berhadapan dua kepentingan yang sama tetapi berbeda sifatnya. Pemerintah maupun lembaga swasta segera ingin membantu korban tetapi harus tepat sasaran dan terbebas dari kebocoran dan penyimpangall. Bantuan tepat sasaran harus didukung oleh data korban yang cermat. Dalam keadaan demikian pengumpulan data korban memerlukan waktu. Korban manusia, kerusakan rumah tinggal perlu dilakukan segera, setelah aıperoleh data perlu dilaporkan kepada pemerintah setempat, selanjutnya diteruskan kepada camat, bupati, dan gubernur. Atas dasar laporan tersebut gubernur meneruskan untuk pemerintah pusat. Data laporan tersebut tidak serta merta diterima, akan tetapi perlu veriflkasi kebenaran data iaporan tersebut. Keadaan demikian tentu saja memerlukan waktu sehingga bantuan tidak segera dapat diterimakan kepada yang berhak. Sebaliknya, bagi korban oleh karena keadaan, memeriukan dengan segera karena rumah tinggai porak poranda, harta benda dan cadangan pangan dalam keadaan rusak. Perabotan rumah dalam keadaan rusak sehingga untuk beberapa hari tidak dapat menyediakan makanan untuk keluarganya. Dalam keadaan demikian timbul inisiatif pendirian posko dan dapur umum. Dengan cara ini untuk sementara kebutuhan mendesak dapat dipenuhi.

\section{Pasca gempa}

Penanganan korban pasca gempa menjadi hal penting. Harta benda dan rumah tinggal yang hilang dan rusak perlu dilakukan tindakan yang tepat. Kerusakan fisik dengan bantuan pemerintah sekalipun, tidak dengan segera dapat diatasi. Tetapi adanya gangguan yang bersifat nonfisik memerlukan waktu yang relatif lama. Dalam keadaan demikian perlu pendampingan yang tepat sasaran dan harus telaten oleh tenaga-tenaga yang mempunyai kemampuan memadai.

Perlu tindakan rehabilitasi dan stabilisasi dalam waktu yang cukup lama. Kerusakan fisik yang berupa bangunan fisik berangsur-angsur menuju pada keadaan yang memenuhi syarat huni. Bantuan yang 
dijanjikan pemerintah pusat sebagian sudah dapat direalisasi. Dana rehabilitasi kerusakan bangunan diberikan secara bertahap. Sampai dengan tulisan ini dibuat, bantuan tahap kedua (bulan April 2007) sedang akan dicairkan. Ini berarti apa yang dijanjikan pemerintah sekalipun datangnya terlambat tetapi akhirnya sampai juga. Bupati Bantul memprediksi bahwa proses rehabilitasi dan stabilisasi baru akan selesai Súmpai tahun 2008. Dengan demikian adanya gempa bumi sebagai bencana alam dalam penanganan korban memerlukan waktu yang lama.

\section{Upaya Pemerintah}

Indonesia merupakan daerah dengan potensi resiko gempa yang tinggi. Karena. itu, selain mempelajari proses terjadinya gempa bumi, kita masih harus mau belajar dari pengalaman masa lalu agar mampu meminimalisasi dampak gempa bumi. Dengan mengetahui paradigma bencana gempa bumi, maka kita akan bijaksana dalam menyikapinya. Untuk jangka panjang, pemerintah bersama-sama peneliti ilmu kebumian (geologi, g€ografi, geofisika) perlu membuat peta zonasi gempa bumi tektonik. Peta tersebut secara global sudah ada, namun perlu dikembangkan peta yang lebih detail dan rinci, misalnya peta zonasi gempa untuk setiap provinsi atau bahkan setingkat kabupaten, disertai dengan peraturar, bangunan tahan gempa (Herry Kurniawan, 2006).

Untuk jangka menengah, perlu melakukan riset yang lebih rinci di setiap segmen patahan (sesar) aktif seperti Sesar Opak (Bantuł), Sesar Menoreh (Kulon Progo), serta sesar-sesar mikro aktif lainnya, yang sering memicu terjadinya gempa bumi tektonik. Pada tahap itu, perlu dibuat peta zonasi gempa buini yang lebih rinci untuk setiap daerah kabupaten/kota.

Bahkan perlu secepatnya melakukan penyuluhan bencana di berbagai u'ilayah Tanah Air yang rawan gempa bumi, disarankan kepada penduduk untuk tidak bermukim di wilayah yang diperkirakan rawan gempa bumi. Melalui dunia pendidikan formal, pendidikan ilmu kebumian, terutama geografi yang diajarkan di sekolah menengah perlu lebih dioptimalkan. Perlu pula dilakukan studi deformasi kerak bumi dengan jalan pemantauan dan monitoring gempa bumi mikro, pergerakan kerak bumi, memetakan sesar-sesar aktif, mempelajari karakteristik seismologi suatu daerah dan lain sebagainya. 
Terjadinya gempa bumi tidak dapat dicegah, tetapi para pakar dapat memprediksi dan melakukan langkah antisipatif. Untuk meminimalisiasi dampak gempa maupun tsunami di Indonesia, pemerintah harus segera melakukan penelitian yang intensif tentang segala sesuatu terkait sumber gempa bumi dan tsunami di seluruh wilayah Indonesia. Pemerintah juga diharapkan menjalin kerja sama regional dengan negaranegara di kawasan Asia Tenggara, Asia Selatan, dan Pasifik guna mengembangkan sistem peringatan dini (early warning system). Selain itu, harus memberdayakan keterlibatan dunia pendidikan perguruan tinggi. Artinya, ilmu geofisika harus ditempatkan pada level kepentingan yang lebih tinggi dari yang ada sekarang.

\section{Penutup}

Bencana alam yang terjadi di Kabupaten Bantul, Kulon Progo, dan Klaten menyisakan beberapa catatan:

1. Kerusakan fisik alami dan bangunan mengganggu aktivitas penduduk dalam menggerakkan ekonomi;

2. Bencana alam terutama yang menimbulkan korban manusia, harta benda, dan tempat tinggal menggugah rasa solidaritas dan sirnpati sesama warga masyarakat dan bangsa;

3. Bantuan yang diberikan bagi korban bervariasi baik asal maupun macamnya;

4. Memunculkan ide-ide baru yang ditawarkan oleh para pakar terkait dengan bangunan rumah tinggal dan bangunan pelayanan publik yang tahan gempa;

5. Partisipasi dunia usaha terutama produsen material bangunan pokok memberikan keringanan harga yang terjangkau;

6. Pemerintah pusat, daerah, memberikan bantuan berupa dana, obatobatan, dan pakaian untuk rehabilitasi fisik;

7. Lembaga swadaya masyarakat dalam dan luar negeri dengan sifat dan cara masing-masing memberikan bantuan untuk meringankan beban para korban;

8. Perorangan, oleh karena hubungan perkerabatan maupun pertemanan dengan caranya sendiri memberi bantuan. Bantuan diberikan kepada perorangan, yayasan, dan lembaga secara langsung; 
9. Catatan lain yang perlu diketengahkan di sini adanya dampak ikutan yang belum atau tidak diperhitungkan sebelumnya;

10. Pendaftaran korban belum dapat tepat sesuai dengan kenyataan. Hal ini dapat terjadi karena dalam suasana mencekam terdapat upaya yang cepat, tetapi kurang tepat sehingga ada korban yang tidak masuk dalam daftar berakibat tidak mendapat bantuan;

11. Akibat lain adanya keberanian berunjuk rasa dan somasi terhadap ketua Pokja maupun ketua Rukun Warga (RW), Ketua Rukun Tetangga (RT), karena adanya ketidakpuasan cara kerja. Dalam penyaluran bantuan tidak sedikit yang menghadapi masalah;

12. Terdapat ketimpangan perolehan bantuan satu daerah bencana dengan yang lain, sehingga menimbulkan kecemburuan sosial;

13. Terdapat sekelompok orang yang menggunakan kesempatan untuk meraup keuntungan dalam suasana penderitaan;

14. Adanya aliran bantuan yang berasal dari sumber yang berbeda dan macam bantuan yang berbeda menyebabkan orang yang kurang kuat pendirian dan imannya dapat tergelincir dalam perbuatan curang. Hal ini dapat terjadi oleh karena tidak biasa dihadapi. Pada keadaan demikian orang menjadi bingung, sengaja atau tidak, berbuat curang. Kekurang hati-hatian dapat berbuat menyimpang, lupa dana untuk para korban;

15.Terdapat aparat desa yang terpaksa diberhentikan dari jabatannya karena kecurangannya diketahui dengan bukti dan saksi yang dapat dipertanggung jawabkan.

16. Bencana alam tidak diharapkan, tetapi pasti terjadi. Kapan waktunya, di daırah mana, tidak atau belum dapat diperkirakan dengan tepat. Marıusia hanya dapat bersikap waspada dan berusaha untuk meminimalisir akibat yang akan diderita.

\section{Daftar Pustaka}

Herry Kurniawan. 2006. Pemerintah Periu Meminimalisasi Dampak Gempa. http://unisosdem.org. 
II Aspek Sosial Gempa Bumi 27 Mei 2006 di Kabupaten Bantul

Suparlan. 2006. Menyikapi dengan Arif Emergency Response. http://www.walhi-jogja.or..id.

Insist. 2006. Penanganan Bencana Gempa. http://insist.or.id. 